\title{
Digestion kinetics of NDF in dairy cows fed silages from primary growth and regrowth of grass
}

\author{
K. Kuoppala ${ }^{1,3}$, M. Rinne ${ }^{1}$, S. Ahvenjärvi', \\ J. Nousiainen ${ }^{2}$ and P. Huhtanen ${ }^{1}$ \\ ${ }^{1}$ MTT Agrifood Research Finland, Animal Production Research \\ FIN-31600 Jokioinen, Finland \\ ${ }^{2}$ Valio Ltd, Farm Services \\ P.O. Box 10, FIN-00039 Valio, Finland
}

\begin{abstract}
Two grass silages from primary growth $(\mathrm{PG})$ and two from regrowth $(\mathrm{RG})$ were investigated in a $4 \times 4$ Latin square experiment by rumen cannulated dairy cows. Digestion kinetics of NDF was determined by rumen evacuations and the omasal canal flow measurements. Dry matter intake of PG was higher, rumen content of indigestible NDF (INDF) lower and passage rate of INDF higher in PG than in RG. Rumen contents of NDF and INDF increased with progressing growth stage of grass within harvest. It is concluded that intake of early cut PG and both RG silages was not limited by rumen fill alone.
\end{abstract}

KEY WORDS: indigestible NDF, digestible NDF, milk production, rumen evacuation, omasal canal sampling

\section{INTRODUCTION}

The intake of silage is markedly affected by digestibility. The decrease in silage dry matter $(\mathrm{DM})$ intake has been on average $0.16 \mathrm{~kg}$ and in milk yield $0.3-0.5 \mathrm{~kg}$ when D-value (digestible organic matter, $\mathrm{g} / \mathrm{kg} \mathrm{DM}$ ) has decreased by $10 \mathrm{~g}$ per $\mathrm{kg} \mathrm{DM}$ (Rinne et al., 2000). The quality and production potential of regrowth silages has not been investigated very widely. In our recent milk production experiment the intake of regrowth silages was smaller and the cows produced less milk than those consuming primary growth silage of comparable D-value (Kuoppala et al., unpublished).

The intake and digestibility of a feed depends on the rate and extent of neutral detergent fibre (NDF) digestion in the rumen, the rate of passage from the rumen and the particle size reduction. Rinne et al. (2002) reported that the decrease in digestibility clearly affected rumen functions: the passage rate of NDF and

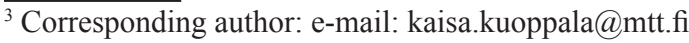


indigestible NDF (INDF), rumen pool size of DM, NDF and INDF increased when the digestibility of primary growth silage decreased.

The objective of the present study was to investigate the differences in digestion kinetics of NDF in order to study the intake limiting factors when dairy cows consume silages prepared from primary growth or regrowth of grass.

\section{MATERIAL AND METHODS}

Two primary growth (PG) and two regrowth (RG) were made from mixed timothy (Phleum pratense) - meadow fescue (Festuca pratensis) sward in 2002 in Jokioinen, Finland $\left(61^{\circ} \mathrm{N}\right)$. PG silages were harvested on 5 June at early (E) and on 17 June at late (L) growth stage. RG silages were harvested on 29 July (LE; primary growth cut on 17 June) and on 12 August (EL; primary growth cut on 5 June). The grass was cut with mower conditioner, wilted approximately $4 \mathrm{~h}$ and harvested with precision chop harvester. Grass was preserved with a formic-acid based additive $(5.41 / \mathrm{t})$ in bunker silos.

Table 1. Chemical composition of feeds

\begin{tabular}{|c|c|c|c|c|c|}
\hline \multirow[b]{3}{*}{ Harvest date in 2002} & \multicolumn{2}{|c|}{ Primary growth } & \multicolumn{2}{|c|}{ Regrowth } & \multirow{3}{*}{ Concentrate } \\
\hline & $E$ & $\mathrm{~L}$ & $\mathrm{LE}$ & EL & \\
\hline & 5 June & 17 June & 29 July & 12 August & \\
\hline Harvest date of primary growth & - & - & 17 June & 5 June & \\
\hline Dry matter, $\mathrm{g} / \mathrm{kg}$ & 283 & 283 & 228 & 334 & 862 \\
\hline \multicolumn{6}{|l|}{ Chemical composition, $\mathrm{g} / \mathrm{kg} D M$} \\
\hline ash & 82 & 68 & 98 & 90 & 80 \\
\hline crude protein & 155 & 127 & 157 & 116 & 179 \\
\hline NDF & 498 & 589 & 513 & 538 & 256 \\
\hline INDF & 50 & 97 & 60 & 93 & 51 \\
\hline DNDF & 448 & 492 & 453 & 445 & 205 \\
\hline D-value $^{1}, \mathrm{~g} / \mathrm{kg} \mathrm{DM}$ & 704 & 644 & 664 & 609 & \\
\hline $\mathrm{ME}, \mathrm{MJ} / \mathrm{kg} \mathrm{DM}$ & 11.3 & 10.3 & 10.6 & 9.74 & 12.4 \\
\hline
\end{tabular}

${ }^{1} \mathrm{D}$-value (digestible organic matter, $\mathrm{g} / \mathrm{kg}$ ) of silages determined with sheep by total faecal collection; NDF- neutral detergent fibre, INDF- indigestible, DNDF- digestible NDF

The four silages were fed with $8 \mathrm{~kg} / \mathrm{d}$ concentrates to four rumen cannulated dairy cows in a $4 \times 4$ Latin square design. The omasal canal flow and digestibility of nutrients were measured by triple-marker method as described by Ahvenjärvi et al. (2000). Digestion kinetics was determined by the rumen evacuation method as described by Rinne et al. (2002). Indigestible NDF was determined by $12 \mathrm{~d}$ ruminal incubation in dairy cows fed forage-rich diets and using nylon bags with a pore size of $17 \mu \mathrm{m}$ (Huhtanen et al., 1994). Digestible NDF was calculated as NDF minus INDF. The in vivo D-value was determined with sheep fed at maintenance level by total collection of faeces. 


\section{RESULTS AND DISCUSSION}

The fermentation quality of all silages was good $(\mathrm{pH}$ on average 4.1 and ammonium-N $56 \mathrm{~g}$ per $\mathrm{kg}$ total N). The content of NDF and INDF increased and the D-value of silages decreased with advancing growth stage both in PG and RG silages (Table 1). RG-values of NDF and INDF were intermediate to PG-values.

DMintake of $P G$ silages was higher $(\mathrm{P}<0.01)$ than that of $R G$ silages despite of lower content of NDF in RG silages (Table2). HigherD-value of LE ( $664 \mathrm{~g} / \mathrm{kgDM}$ ) compared to $\mathrm{L}(644 \mathrm{~g} / \mathrm{kg} \mathrm{DM})$ did not increase the intake which differed from earlier results in primary growth (Rinne, 2000). Reason for that may be the confounding effect of DM content, which was lower in LE than in L (228 vs $283 \mathrm{~g} / \mathrm{kg}$, respectively).

Table 2. The effect of harvest and growth stage of grass silage on daily feed and nutrient intake, rumen contents and digestion kinetics of neutral detergent fibre (NDF) in dairy cows

\begin{tabular}{|c|c|c|c|c|c|c|c|c|}
\hline & \multicolumn{2}{|c|}{ Primary growth } & \multicolumn{2}{|c|}{ Regrowth } & \multirow[t]{2}{*}{ SEM } & \multicolumn{3}{|c|}{$\begin{array}{c}\text { Statistical } \\
\text { significance }^{1}\end{array}$} \\
\hline & $\mathrm{E}$ & $\mathrm{L}$ & LE & EL & & $\mathrm{C}_{1}$ & $\mathrm{C}_{2}$ & $\mathrm{C}_{3}$ \\
\hline \multicolumn{9}{|c|}{ Feed and nutrient intake, $\mathrm{kg} / \mathrm{d}$} \\
\hline silage DM & $13.8^{\circ}$ & 12.2 & 11.2 & 10.6 & 0.38 & $* * *$ & $*$ & \\
\hline total DM & 20.9 & 19.2 & 18.3 & 17.6 & 0.38 & $* * *$ & $*$ & \\
\hline organic matter & 19.2 & 17.9 & 16.6 & 16.1 & 0.35 & $* * *$ & $*$ & \\
\hline crude protein & 3.40 & 2.82 & 3.01 & 2.48 & 0.080 & $* *$ & $* *$ & $* *$ \\
\hline $\mathrm{NDF}$ & 8.63 & 8.91 & 7.48 & 7.42 & 0.220 & $* * *$ & & \\
\hline DNDF & 7.58 & 7.37 & 6.45 & 6.03 & 0.193 & $* * *$ & & \\
\hline INDF & 1.06 & 1.55 & 1.03 & 1.35 & 0.035 & $*$ & $* * *$ & $* * *$ \\
\hline \multicolumn{9}{|l|}{ Rumen contents, $\mathrm{kg}$} \\
\hline dry matter & 11.3 & 12.6 & 12.0 & 12.3 & 0.38 & & $*$ & \\
\hline organic matter & 10.3 & 11.6 & 10.7 & 11.1 & 0.35 & & $*$ & \\
\hline NDF & 6.65 & 8.11 & 6.52 & 7.52 & 0.252 & & $* *$ & * \\
\hline DNDF & 5.10 & 5.77 & 4.64 & 4.98 & 0.252 & o & & \\
\hline INDF & 1.55 & 2.34 & 1.88 & 2.54 & 0.046 & $* *$ & $* * *$ & $* * *$ \\
\hline NDF flow, $\mathrm{kg} / \mathrm{d}$ & 2.90 & 4.36 & 2.87 & 3.61 & 0.114 & $*$ & $* * *$ & $* *$ \\
\hline \multicolumn{9}{|c|}{ NDF digestibility, $g / g$} \\
\hline ruminal & 0.661 & 0.511 & 0.616 & 0.515 & 0.0122 & & $* * *$ & $* *$ \\
\hline total tract & 0.659 & 0.589 & 0.686 & 0.579 & 0.0116 & & $* *$ & $* * *$ \\
\hline \multicolumn{9}{|c|}{ Digestion kinetics, $1 / h$} \\
\hline DNDF, $k_{i}$ & 0.0620 & 0.0543 & 0.0594 & 0.0517 & 0.00292 & & & \\
\hline DNDF, $\mathrm{k}_{\mathrm{d}}$ & 0.0462 & 0.0379 & 0.0461 & 0.0357 & 0.00230 & & $*$ & $*$ \\
\hline DNDF, $\mathrm{k}_{\mathrm{p}}^{\mathrm{d}}$ & 0.0157 & 0.0164 & 0.0133 & 0.0160 & 0.00103 & & & \\
\hline INDF, $\mathrm{k}_{\mathrm{n}}^{\mathrm{p}}$ & 0.0279 & 0.0260 & 0.0207 & 0.0208 & 0.00142 & $* *$ & & \\
\hline
\end{tabular}

${ }^{1}$ orthogonal contrasts: $\mathrm{C}_{1}$ - primary growth vs regrowth silages, $\mathrm{C}_{2}-\mathrm{E}$ vs $\mathrm{L}, \mathrm{C}_{3}$ - LE vs EL significance: $* * * \mathrm{P}<0.001,{ }^{*} \mathrm{P}<0.01,{ }^{*} \mathrm{P}<0.05, \mathrm{P}<0.10$; INDF- indigestible NDF; DNDF -digestible $\mathrm{NDF} ; \mathrm{k}_{\mathrm{i}}$ - rate of intake, $\mathrm{k}_{\mathrm{d}}$ - rate of digestion, $\mathrm{k}_{\mathrm{p}}$ - rate of passage 
The average rumen content of DM was lowest on $\mathrm{E}$ in spite of highest DM intake on that diet. Decreased digestibility of PG induced significant increase in DM, OM, NDF and INDF contents of rumen. With RG silages the increase was significant only in NDF and INDF content. The average rumen content of INDF was lower $(\mathrm{P}<0.01)$ in $\mathrm{PG}$ silages than in $\mathrm{RG}$ silages. The daily ruminal outflow of NDF was higher $(\mathrm{P}<0.05)$ in $\mathrm{PG}$ silages than in $\mathrm{RG}$ silages and the progressing growth stage increased it in both harvests. Ruminal and total tract digestibility of NDF decreased with growth stage in both harvests. The difference between harvests was not significant.

There were no differences between PG and RG or within harvests in passage rate of DNDF. Instead, the digestion rate of it decreased with progressing growth stage with no differences between harvests. The passage rate of INDF was lower in $R G$ silages $(\mathrm{P}<0.01)$ with no differences within harvests.

\section{CONCLUSIONS}

Based on rumen pool data, intake of early cut PG and both RG silages was not limited by rumen fill alone.

\section{REFERENCES}

Ahvenjärvi S., Vanhatalo A., Huhtanen P., Varvikko T., 2000. Determination of reticulo-rumen and whole-stomach digestion in lactating cows by omasal canal or duodenal sampling. Brit. J. Nutr. 83, 67-77

Huhtanen P., Kaustell K., Jaakkola S., 1994. The use of internal markers to predict total digestibility and duodenal flow of nutrients in cattle given six different diets. Anim. Feed Sci. Tech. 48, 211-227

Rinne M., 2000. Influence of the timing of the harvest of primary grass growth on herbage quality and subsequent digestion and performance in the ruminant animal. Academic Dissertation, University of Helsinki, Department of Animal Science, Publications 54, pp. $42+5$ encl., http: //ethesis.helsinki.fi/julkaisut/maa/kotie/vk/rinne/

Rinne M., Huhtanen P., Jaakkola S., 2002. Digestive processes of dairy cows fed silages harvested at four stages of grass maturity. J. Anim. Sci. 80, 1986-1998 